\title{
The Control of Microcystis spp. Bloom by Combining Indigenous Denitrifying Bacteria From Sutami Reservoir with Fimbristylis globulosa and Vetiveria zizanoides
}

\author{
Bayu Agung Prahardika, Catur Retnaningdyah*, Suharjono
}

Biology Department, Faculty of Mathematics and Natural Sciences, Brawijaya University, Malang, Indonesia

\begin{abstract}
The purpose of this research is to know the ability of polyculture macrophyte (Fimbristylis globulosa and Vetiveria zizanoides) and the combination of both with consortium of indigenous denitrifying bacteria from Sutami reservoir that was added by Microcystis spp. or not to reduce the concentration of nitrate, dissolved phosphate and the carrying capacity of Microcystis spp. The experiment was done in a medium filled up with Sutami reservoir water enriched with $16 \mathrm{ppm}$ of nitrate and $0.4 \mathrm{ppm}$ of phosphate. The denitrifying bacteria used in this research were DR-14, DU-27-1, DU-30-1, DU-30-2, TA-8 and DU-27-4 isolated from Sutami reservoir. The treatments were incubated within 15 days. Microcystis spp. abundance was calculated every day, but the measurement of the concentration of nitrate and dissolved phosphate was done every six days. The results showed that both treatment and the combination of both macrophytes with a consortium of denitrifying indigenous bacteria were added or not either Microcystis able to reduce nitrate at $99 \%$ and $93-99 \%$ orthophosphoric. The combination of macrophytes with denitrifying indigenous bacterial consortium from Sutami reservoir was able to inhibit the carrying capacity of Microcystis spp. highest up to $47.87 \%$. They could also significantly reduce the abundance of Microcystis from $10^{7}$ cells $/ \mathrm{mL}$ in earlier days of the treatment into $0.35 \times 10^{4}$ cells $/ \mathrm{mL}$ after fifteen days of incubation.
\end{abstract}

Keywords: control of Microcystis, denitrifying bacteria, Fimbristylis globulosa, Sutami reservoir, Vetiveria zizanoides

\section{INTRODUCTION}

Sutami reservoir located in the Karangkates Village, Sumber Pucung District, Malang, is the largest reservoir in the province of East Java. Sutami reservoir is one of the artificial aquatic ecosystems that are multifunctions. Some of them include electricity generation, flood control, irrigation for agriculture, fishery as well as one of tourist attractions in Malang [1]. In 2002, the Sutami Reservoir once bloomed Microcystis spp. The result of the monitoring carried out in 2004-2006, Microcystis spp., together with Ceratium and Synedra always had the highest number of population in the reservoir [2].

This phenomenon was probably caused by an increase in nutrients resulting in nutrient

\footnotetext{
${ }^{*}$ Corresponding author: Catur Retnaningdyah

Biology Department, Faculty of Mathematics and Natural

Sciences, Brawijaya University, Jl. Veteran, Malang,

Indonesia 65145

Email: catur@ub.ac.id
}

concentration and imbalance ratios that existed in these waters (eutrophication). Microalgal explosion resulted in the reduced productivity of fisheries. Microcystis spp. is one type of cyanobacteria that can produce toxins which are harmful to other living things [3]. Accordingly, it is used in this research effort control, using bioremediumtion techniques to incorporate the denitrifying indigenous bacterial consortium in Sutami reservoirs and macrophite. The macrophite used is Mendong (Fimbristylis globulosa) and Akar Wangi (Vetiveria zizanoides).

\section{MATERIALS AND METHODS}

The experimental study was conducted purely in a laboratory scale using a completely randomized design with treatments as follows:

1. a. Sutami reservoir water + Wetland soil, and + Microcystis spp.

b. Sutami reservoir water + Wetland soil, and without Microcystis spp.

2. a. (F. globulosa $+V$. rizanoides $)+$ Sutami reservoir water + Wetland soil, and + 
Microcystis spp.

b. (F. globulosa $+V$. zizanoides $)+$ Sutami reservoir water + Wetland soil, and without Microcystis spp.

3. a. StokKulturBakteri + Sutami reservoir water + Wetland soil, and + Microcystis spp.

b. StokKulturBakteri + Sutami reservoir water + Wetland soil, without Microcystis spp.

4. a. StokKulturBakteri $+($ F. globulosa $+V$. zizanoides) + Sutami reservoir water + Wetland soil, and + Microcystis spp. StokKulturBakteri + (F. globulosa $+V$.

b. zizanoides) + Sutami reservoir water + Wetland soil, and without Microcystis spp.

Thus, the treatments in this study consisted of eight repetitive actions of each three times at the same time. Observations made during the fifteen days, including the calculation of the number of Microcystis spp., was conducted every day and the measurement of levels of nitrate and orthophosphoric was conducted every six times a day.

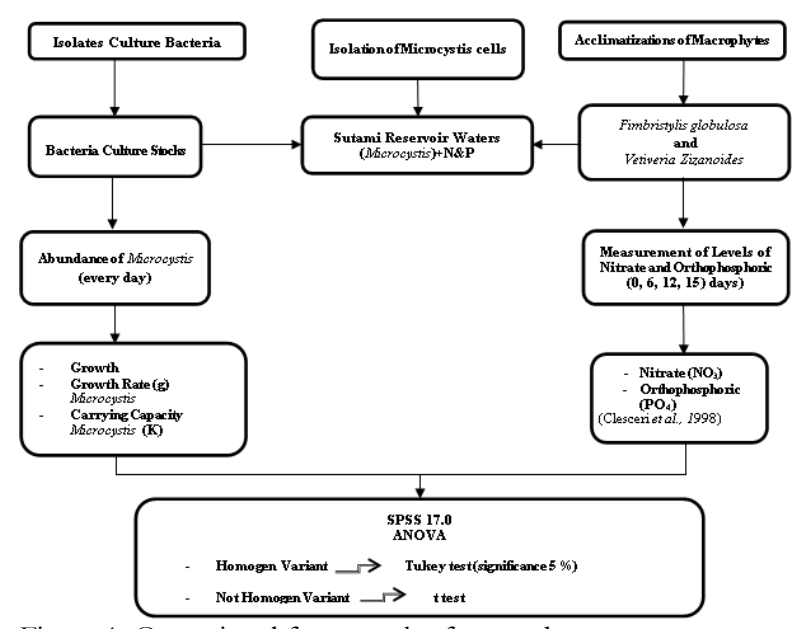

Figure 1. Operational framework of research

Potential test was conducted in a bucket with a diameter of $30 \mathrm{~cm}$. The medium comprised a bucket of water 6 litres Sutami reservoir and 12 $\mathrm{kg}$ wetland soil treated with the addition of nitrate administration of $16 \mathrm{mg} / \mathrm{L}$ and orthophosphoric as much as $0.4 \mathrm{mg} / \mathrm{L}$. The kinds of macrophite used in this study were different from one to another depending on the weight of each macrophite calculated from the area. The weight was valued by closing the Macrophite that was equal to $25 \%$ of the surface area of the bucket. The assay was performed as a preliminary study. All treatments performed an addition of nitrate of $16 \mathrm{mg} / \mathrm{L}$ and orthophosphoric as much as $0.4 \mathrm{mg} / \mathrm{L}$. Each treatment was repeated three times at the same time, and each was carried out in a bucket with a diameter of $30 \mathrm{~cm}$. The observations were made within 15 days and conducted in a greenhouse.

\section{RESULTS AND DISCUSSION}

The nitrate concentrations at the beginning of the treatment varied from 18.51 to $23.32 \mathrm{mg} / \mathrm{L}$ (Figure 2). This ranging value was previously anticipated because of the variation in nitrate content in the water from Sutami reservoirs, the medium used for the treatment. Based on the $t$ test each time the concentration of nitrate observations is compared with the day-to-zero (Figure 2), it can be concluded that the remediumtion process resulted in lower nitrate concentrations significantly in each treatment medium from the sixth day of observation, that is to be $3-8 \mathrm{mg} / \mathrm{L}$ the percentage of $57-83 \%$ reduction. Decrease in the higher on the day of the twelfth and fifteenth, respectively, to 0.02 to $0.65 \mathrm{mg} / \mathrm{L}$ and 0.01 to $0.09 \mathrm{mg} / \mathrm{L}$. The percentage decrease in nitrate in the medium each day for twelve observations is $96-99 \%$, whereas on the fifteenth day of observation is more than $99 \%$. Decrease in nitrate concentrations that occur are expected to affect the density of Microcystis cells in the medium treatment, which lowers the density of Microcystis cells, given the minimum nitrate concentration for the growth of algae in aquatic ecosystems is approximately $0.259 \mathrm{mg} / \mathrm{L}$ [4].

The nitrate concentrations in the medium control without the addition of nitrate decreased the number of Microcystis in the fifteenth day up to $99.68 \%$, whereas in the control medium with the addition of nitrate, its number decreased approximately $99.74 \%$. The cells of Microcystis spp. were able to utilize nitrate as a nitrogen source to form amino acids, chlorophyll and other organic compounds [5]. The decrease of nitrate in the medium macrophyte comprising the combination of F. globulosa and $V$. zizanoides without the addition of Microcystis in the fifteenth day reached about $99.94 \%$, whereas the macrophyte combination in the medium with the addition of Microcystis was approximately $99.84 \%$. The lower decrease in the nitrate macrophyte combination medium with the addition of Microcystis was allegedly caused by competition in the utilization of nitrate.

The decrease in nitrate concentration in the denitrifying bacteria consortium medium without the addition of Microcystis in the fifteenth day reached about $99.59 \%$, while in the denitrifying 

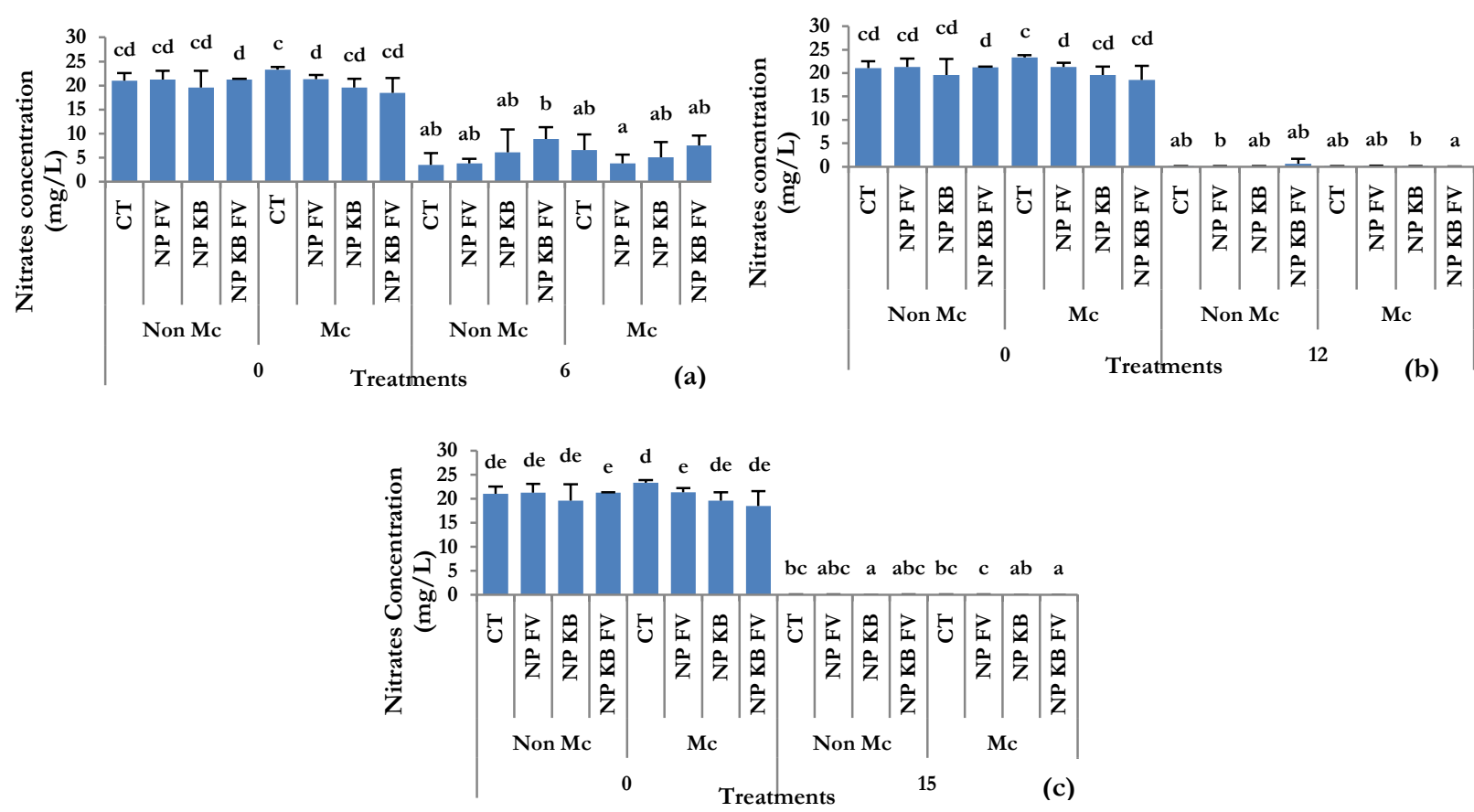

Figure 2. Comparison of the observed 0-6 days (a), 0-12 days (b), and 0-15 days (c). KT=Control; NPFV= Nitrate\&Phosphate $+(F$. globulosa $),($ V. zizanoides $) ; \mathrm{NPKB}=$ Nitrate\&Phosphate + Denitrifying bacteria indigenous consortium. The same letters on the block showed no significantly different by ANOVA followed by t test $\alpha 0.05$

bacteria consortium medium with the addition of Microcystis the decrease was approximately $99.89 \%$. The medium with the addition of Microcystis appeared to enable positive interaction between denitrifying bacteria consortium and Microcystis, so both organisms benefited from each other's nitrate contents taken from the environment. The denitrifying bacteria have the ability to secrete enzymes to break down nitrate reductase. The nitrate compounds are used as sources of nitrogen for metabolic processes in the growth period [6]. The decrease in nitrate concentration in the denitrifying bacteria consortium with a macrophyte combination medium, which was able to reduce the nitrate without the addition of Microcystis in the fifteenth day reached about $99.81 \%$. Yet, in the same medium treatment with the addition of Microcystis, the decrease was approximately $99.93 \%$. The decrease in the nitrate concentration in the sizable amount was allegedly due to the positive interaction between a denitrifying bacteria consortium in the combination of both macrophytes.

As was the case in nitrate, the concentration of orthophosphoric at the beginning of each treatment was also different $(0.30$ to $1.10 \mathrm{mg} / \mathrm{L})$ (Figure 3). This is presumably due to the addition of orthophosphoric content into the Sutami reservoir media as a source of treatment media. The orthophosphoric concentrations in each treatment medium has had a significant decrease $(\mathrm{p}<0.05)$ after six days of incubation ranging from 0.04 to $0.09 \mathrm{mg} / \mathrm{L}$. Nevertheless, on day twelve and fifteen the concentrations increased, each being 0.03 to $0.11 \mathrm{mg} / \mathrm{L}$ and 0.01 to $0.15 \mathrm{mg} / \mathrm{L}$ (Figure 3). The increased value of the orthophosphoric that occurred in the twelfth and fifteenth day of the observation was allegedly caused by the treatment to the activity of phosphate reducing bacteria that naturally exist in both media, the Sutami reservoirs water and the wetland soil. In addition, the cause of the increased value of orthophosphoric return could be derived from the bacterium that caused the orthophosphoric compounds in the soil medium to become dissolved in the water treatment medium [7].

Orthophosphoric overall decline in the media for each day of the sixth observation was about $74-92 \%$, while the decline within twelve days of observation was about $62-94 \%$. The decrease of the concentration of orthophosphoric on the fifteenth day of observation was $51-99 \%$. The decrease in the concentration of the orthophosphoric occurred in connection with Microcystis cell density in the medium treatment, which lowered the density of Microcystis cells. The decrease in phosphate concentration in the control medium either without or with addition of Microcystis until the fifteenth day of each was about 97.71 and $98.03 \%$. This situation indicates that the Sutami reservoirs water has allegedly already contained microorganisms that can 
reduce orthophosphoric. The orthophosphoric's decline in the medium macrophytes addition of Microcystis until the fifteenth day of each was about 99.24 and $93.16 \%$. The macrophyte was able to take advantage from the orthophosphoric for metabolic processes [8].

The orthophosphoric decrease in the bacterial consortium medium either without or with addition of Microcystis until the fifteenth day was around 51.73 and $54.86 \%$. The use of denitrifying bacteria consortium alone was only able to slightly reduce the concentration of orthophosphoric. This situation was probably due to the many who have contained orthophosphoric content in the wetland soil medium. Meanwhile, the decrease of the concentration of orthophosphoric in the denitrifying bacteria consortium indigenous medium to a combination of both macrophyte without or with addition of Microcystis until combinations F. globulosa and $V$. zizanoides both without and with thefifteenth day of each was about 99.65 and $93.69 \%$. The incorporation of denitrifying bacteria consortium with a macrophyte combination was able to reduce the concentration of orthophosphoric in the greatest number. This indicates the positive interaction between the denitrifying bacteria consortium with a macrophyte combination in the use of orthophosphoric. Orthophosphoric is a phosphate compound is dissolved in water, while phosphate is an impetus for the increased use of nitrogen by the organism. When the a sufficient number of phosphate is available, it will trigger the use of nitrate towards the growth of organisms. Yet, when the concentration of phosphate has been exhausted by the growth of organisms, the utilized nitrate will be hampered even if other nutrients are abundant [10].
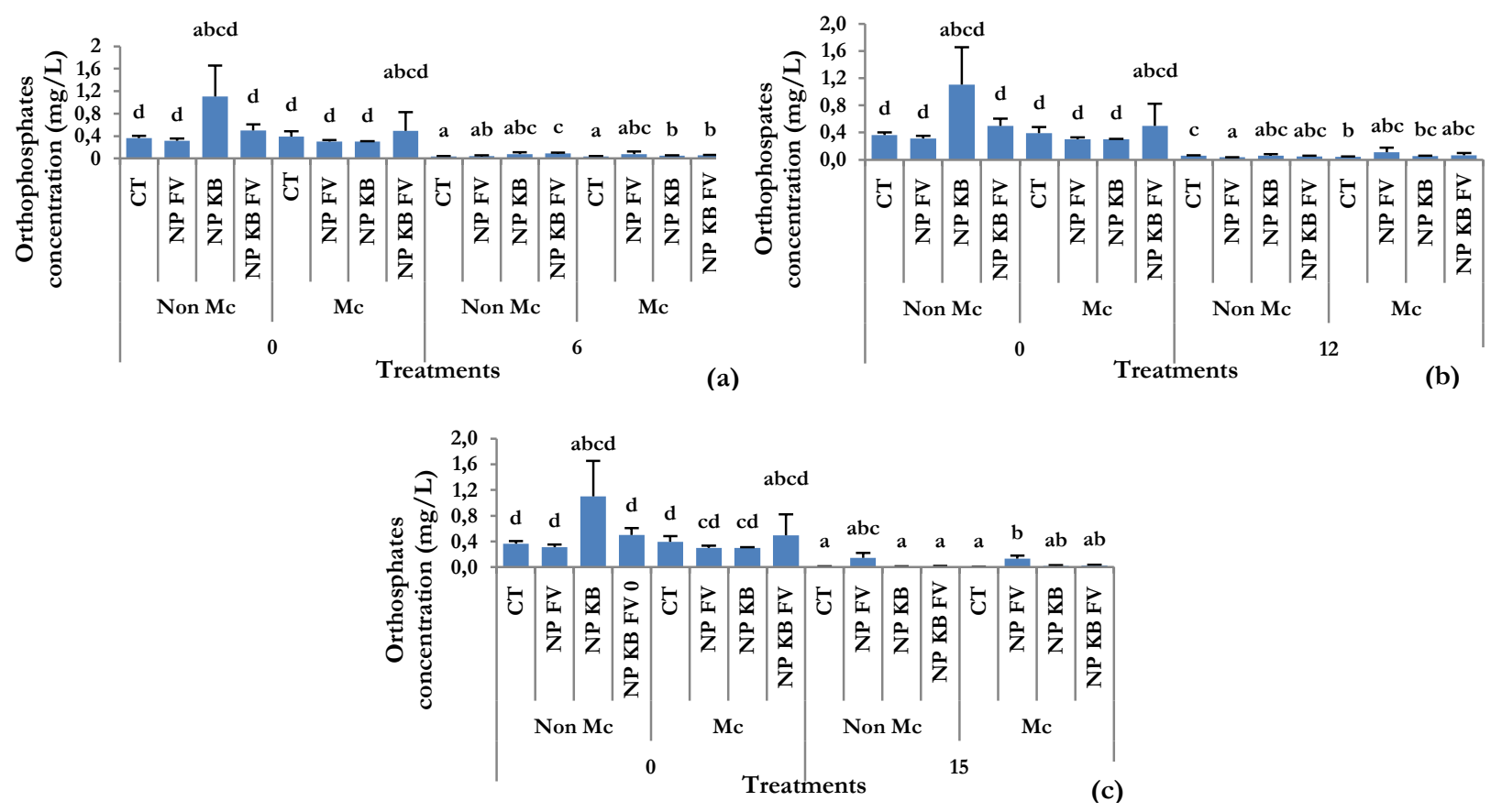

Figure 3. Comparison of the observed 0-6 days (a), 0-12 days (b), and 0-15 days (c). KT=Control; NPFV= Nitrate\&Phosphate $+(F$. globulosa $),($ V rizanoides $) ; \mathrm{NPKB}=$ Nitrate\&Phosphate + Denitrifying bacteria indigenous consortium. The same letters on the block showed no significantly different by ANOVA followed by t test $\alpha 0.05$

The growth curve of Microcystis spp. on each treatment medium is shown in Figure 4. The observations indicate that Microcystis spp cells. medium in each treatment did not experience a phase lag. The cells of Microcystis spp. did not also undergo the phase of adaptation in the new treatment medium. Not the phase lag in each of the treatment medium is thought to be caused due to the addition of nutrients nitrate and orthophosphoric in accordance with the requirements of living Microcystis spp.
Exponential phase of Microcystis spp. cells in control medium and the combination of bacterial consortium with macrophyte of F. globulosa and $V$. zizanoides medium occurred in the fourth day of observations, each of which was $25 \times 10^{4}$ and $13 \times 10^{4}$ cells $/ \mathrm{mL}$. Meanwhile, the exponential phase in combination treatment macrophite $F$. globulosa and $V$. rizanoides medium occurred on the fifth day of observation with a total of $18 \times 10^{4}$ cells $/ \mathrm{mL}$. Then the exponential phase to the treatment of bacterial consortium medium occurred on the fourth day of observation with a 
total of $16 \times 10^{4}$ cells $/ \mathrm{mL}$. Respective medium control treatment, $\mathrm{FV}, \mathrm{KB}$ and $\mathrm{KBFV}$ in stationary phase but not having directly experienced the death phase. Once passing through the exponential phase, the cells of Microcystis spp cells. directly experienced a significant decline.

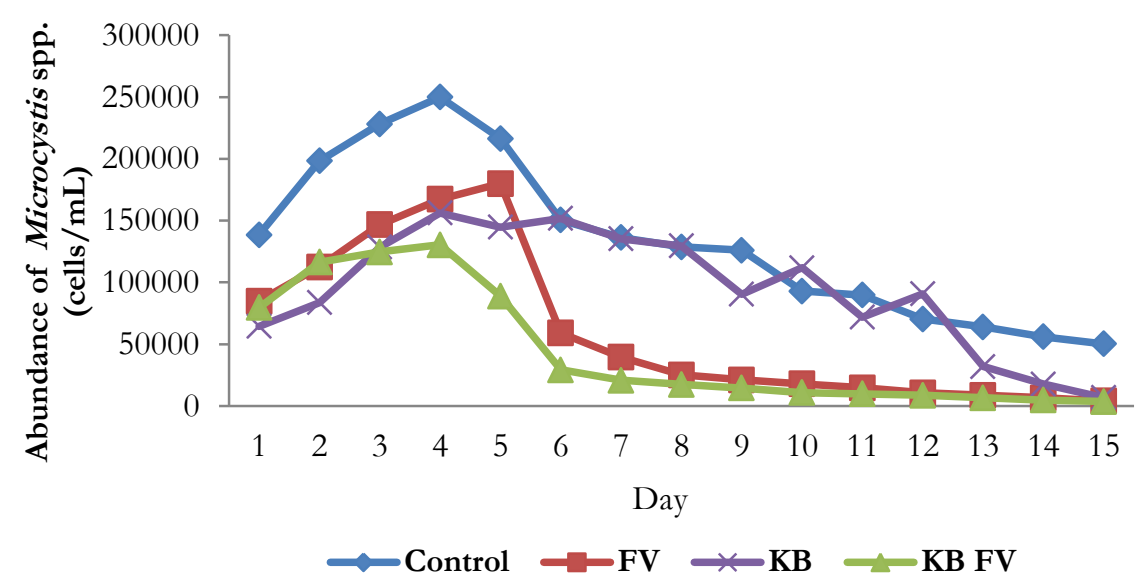

Figure 4. The growth curve of Microcystis spp. medium at various treatment. FV: Combination of F. globulosa dan V. zizanoides; KB: Denitrifying bacteria consortium. Microcystis spp. cells in each treatment medium directly into the exponential growth phase characterized by an increase in cell number of the most high.

The observations in the medium combination of denitrifying bacteria consortium indigenous treatment with a macrophyte $F$. globulosa and $V$. zizanoides showed that it was able to inhibit the growth of Microcystis cells the most if compared with other treatment media. This was indicated by the maximum abundance of Microcystis cells which only occurred until the fourth day of observation with Microcystis cell density of $13 \times 10^{4}$ cells $/ \mathrm{mL}$. It means that the availability of nutrients that support the growth of Microcystis

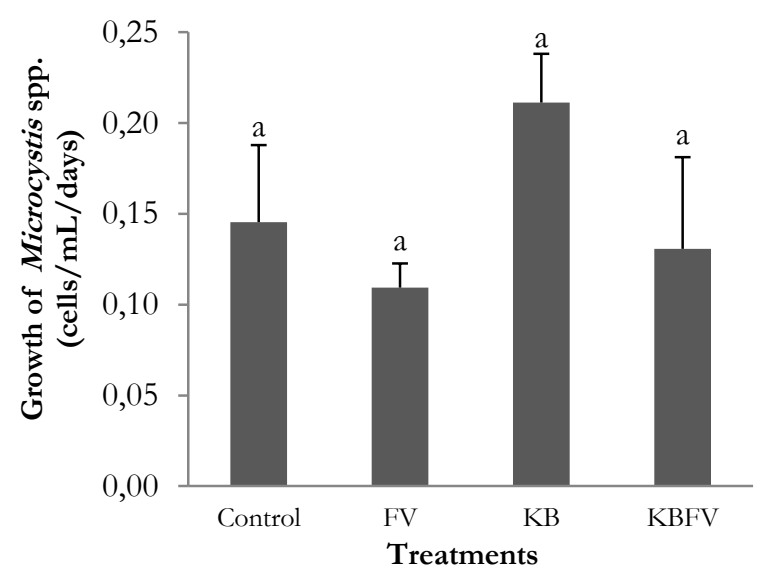

cells in the medium reduced after the fourth day. Moreover, this medium Microcystis cell density on the final day of observation (fifteenth day) has the least density, which is $0.35 \times 10^{4}$ cells $/ \mathrm{mL}$. The highest value of Microcystis cell growth inhibition in this medium was also supported by the significant decrease in nutrient concentrations of nitrate and orthophosphoric since the sixth day of observation, that are $60 \%$ and $86 \%$, respectively.

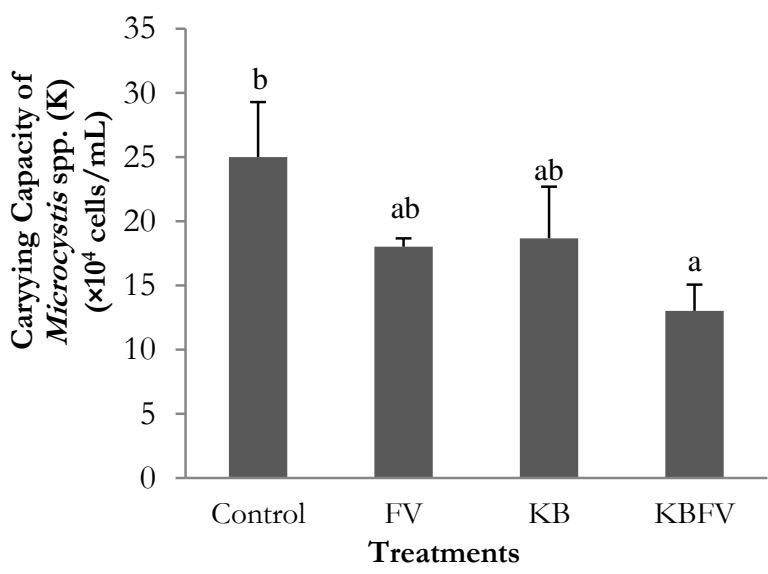

Figure 5. Growth rate (a) and carrying capacity (b) of Microcystis spp. in a variety of different treatment mediumFV. Combination of F. globulosa and V. rizanoides; KB. Bacterial consortium. The same letters on the block showed no difference based on ANOVA test followed by Tukey test HSD (BNJ) at $\alpha 0.05$

The growth rate of Microcystis spp. cell in a variety of treatment medium was obtained from the increase in abundance or density of cells every day. The growth rate shows the relative ecological success of a species of organism to be able to adapt well to the environment or the place of growth medium. The growth rate of Microcystis spp cells. in the control medium was 0.14 cells $/ \mathrm{mL} /$ day, whereas for FV treatment medium, the $\mathrm{KB}$ and $\mathrm{KBFV}$ were respectively 0.11: 0.21 and 0.13 cells $/ \mathrm{mL} /$ day (Figure 5). The growth rate of Microcystis spp. was relatively 
similar to the medium control treatment, $\mathrm{FV}, \mathrm{KB}$ and KBFV ( $p>0.05$ ). The carrying capacity of the medium control, FV, KB and KBFV were $25 \times 10^{4} ; 18 \times 10^{4} ; 19 \times 10^{4}$ and $13 \times 10^{4}$ cells $/ \mathrm{mL}$, respectively. The treatment medium which is the combination of consortium of denitrifying bacteria with macrophyte of F. globulosa and $V$. rizanoides was able to inhibit the growth of Microcystis the most. This indicated that the carrying capacity of the lowest $\left(13 \times 10^{4}\right.$ cells / $\mathrm{mL}$ ) was in medium (Figure 5). These results were supported by the highest percentage of the decrease in the abundance of Microcystis. This was shown in the denitrifying bacteria indigenous consortium medium combined with a macrophyte F. globulosa and $V$. zizanoides which was $47.87 \%$, while in the combination of $F$. globulosa and $V$. rizanoides medium the decrease reached $27.93 \%$ and $23.35 \%$ in the medium denitrifying indigenous bacterial consortium.

\section{CONCLUSION}

The results showed that both treatment and a combination of both macrophytes with a consortium of denitrifying indigenous bacteria were added or not either Microcystis able to reduce nitrate at $99 \%$ and $93-99 \%$ orthophosphoric. The macrophytes combinations with denitrifying indigenous bacterial consortium were able to degrade the carrying capacity of Microcystis spp. at the most, reaching up to $47.87 \%$. The Microcystis's number of $10^{7}$ cells $/ \mathrm{mL}$ in the beginning of the treatment was inhibited as much as $0.35 \times 10^{4}$ cells $/ \mathrm{mL}$ after incubation for fifteen days.

\section{ACKNOWLEDGMENTS}

Thank you for Dr. Catur Retnaningdyah, M.Si. and Dr. Suharjono, M.Si. who have helped to improve this manuscript.

\section{REFERENCES}

1. Soekistijono (2004) Eutrofikasi di waduk sutami: monitoring, evaluasi dan upaya penanganannya, kolokium hasil penelitian dan pengembangan sumber daya air. Perum Jasa Tirta I. Malang.

2. Samino S, Retnaningdyah C (2006) Monitoring dinamika komunitas fitoplankton dan zooplankton di waduk sutami malang periode bulan oktober sampai desember 2004. Research Report Cooperation Jasa Tirta I with the Department of Biology Faculty of Mathematics and Science Certificate No.ID03/0127 UB.
3. Codd GA, Lindsay J, Young MF, Morrison LF, Metcalf JS, (2005) From mass mortalities to management measures, In Huisman J, Matthijs HCP, Visser PM, eds, Harmful cyanobacteriaAquatic Ecology series vol 3, pp 1-23. Springer. Netherlands.

4. Fried SBM, Nothwehr E (2003) Nitrate and phosphate levels positively affect the growth of algae species found in perry pond. Biology Department, Grinnell College. Grinnell.

5. Ruckert GF, Giani A (2004) Effect of nitrate and ammonium on the grwoth and protein concentration of Microcystis viridis Lemmermman (Cyanobacteria), http://www.scielo.br. Accessed on May 24th 2012.

6. Vivian CM, Cabello P, Luque MM, Blasco R, Castillo F (1999) Prokaryotic nitrate reduction: molecular properties and functional distingtion among bacterial nitrate reductases. J. Bacteriol. 181 (21): 6573-6584.

7. Wulandari S, (2001) Efektivitas bakteri pelarut fosfat Pseudomonas sp. terhadap pertumbuhan tanaman kedelai (Glycine max L.) pada tanah podsolik merah kuning. Jurnal Natur Indonesia 4 (1). 56-63.

8. Safaria TN (2012) Ketersediaan dan peranan beberapa bioelement dalam tanah untuk proses pertumbuhan tanaman, http://file.upi.edu/. Accessed on June 7th 2012.

9. Retnaningdyah C, Suharjono, Soegianto A, Irawan B, (2010) Daya dukung dan laju pertumbuhan Microcystis hasil isolasi dari waduk sutami pada berbagai variasi konsentrasi nitrat dan fosfat dalam medium selektif B-12. Biota. 15(3): 354-362. 